Mrtcheld, P. \& Moyle, J. M. (1953). J. gen. Microbiol. 9, 257-272.

\title{
Paths of Phosphate Transfer in Micrococcus pyogenes: Phosphate Turnover in Nucleic Acids and other Fractions
}

\author{
By P. MITCHELL AND JENNIFER M. MOYLE \\ Department of Biochemistry, University of Cambridge
}

SUMMARY: The paths of transfer of phosphate groups during uptake of inorganic orthophosphate by Micrococcus pyogenes var. aureus (strain Duncan) have been studied by following the incorporation of ${ }^{32} \mathrm{P}$-labelled phosphate groups into the phospholipid (LP), acid-soluble inorganic (AI) and organic (AO), deoxyribonucleic acid (DNA), ribonucleic acid (RNA) and glycerophospho-protein complex (PGP) fractions of the cells.

In resting cells a strictly reciprocal exchange of inorganic phosphate across the osmotic barrier is half complete in 70 min. During respiration or growth, phosphate moves inward through the osmotic barrier at the same rate as during rest, but the outward movement is abolished. Phosphate accumulates mainly in the AI, AO and LP during respiration, but in all the fractions during growth. Most of the phosphate of the organic fractions is drawn through the AI. The RNA is formed from the nucleotides of the AO, while the DNA phosphate is derived either directly from the AI or from intermediates in the AO. Little or no turnover of RNA or DNA phosphate occurs during growth, and phosphate is not transferred directly or indirectly from RNA to DNA or vice versa. The PGP, although the major constituent of the mechanically rigid cell envelope, does not participate as a whole in phosphate transfer reactions during rest or respiration; but during growth the amount of PGP increases in proportion to the expansion of cell envelope area. The LP phosphate exhibits rapid turnover during respiration and growth.

The work to be described here was undertaken to obtain information about the process of assimilation of inorganic orthophosphate by Micrococcus pyogenes var. aureus (strain Duncan). The aim was to trace with ${ }^{32} \mathrm{P}$ the paths of entry of phosphate from the suspension medium into the main phosphate fractions of the cells when $(a)$ resting, $(b)$ respiring, and $(c)$ growing. The phosphate fractions selected for study were: the cold $5 \%$ trichloroacetic acid-soluble inorganic (AI) and organic (AO), the phospholipid (LP), deoxyribonucleic acid (DNA), ribonucleic acid (RNA) and glycerophospho-protein complex (PGP) fractions of the cells; and the inorganic phosphate of the medium (mI). All are well known except the PGP, the major constituent of the mechanically rigid cell envelope of $M$. pyogenes, formerly called XSP (Mitchell \& Moyle, 1951b). Essentially the problem was the same as that of Juni, Kamen, Reiner \& Spiegelman (1948) in their studies of phosphate assimilation by baker's yeast. Our treatment differs, however, in one important respect. Spiegelman and his collaborators interpreted their findings in the usual terms of phosphate 'turnover' inferred in many cases from determinations of relative specific activity alone. Much more definite information may be obtained from estimations of the total $\mathbf{P}$ and ${ }^{32} \mathbf{P}$ contents of the phosphate fractions : moreover, interpretation becomes easier and less ambiguous because the total $\mathbf{P}$ and ${ }^{32} \mathbf{P}$ contents 
each possess the property, not shared by the values of relative specific activity, of being additive. Our experiments were therefore designed to make the best use of the following three principles:

(i) the $\mathbf{P}$ content of unit volume of the system (cells + suspension medium) remains constant;

(ii) the ${ }^{32} \mathrm{P}$ content of unit volume of the system remains constant;

(iii) the ratio of ${ }^{32} \mathbf{P}$ to $\mathbf{P}$ passing out of a given phosphate fraction is equal to the ratio of ${ }^{32} \mathbf{P}$ to $\mathbf{P}$ in that fraction.

The validity of these principles is initially dependent on an arrangement of the experimental conditions during phosphate assimilation such that any changes of $\mathbf{P}$ content or volume of the cell suspension as a whole are known. To utilize the principles it must be possible to determine the total $\mathbf{P}$ and ${ }^{32} \mathbf{P}$ contents of the phosphate fractions of the cells at intervals during the progress of assimilation. A fractionation procedure must, therefore, be used in which the phosphate fractions can be separated quantitatively or in known yield in a known state of purity. Principle (ii) also depends upon the duration of the experiment being short in comparison to the half-life of the ${ }^{32} \mathrm{P}(14 \cdot 3$ days) or upon the application of corrections for decay. Principle (iii) requires special consideration. This principle depends upon the assumption that the phosphate passing out of a fraction by a given metabolic path may be regarded as a random sample of the phosphate of the whole fraction. The validity of this assumption will be considered when principle (iii) is applied.

\section{METHODS}

Growth and preparation of organism. Cultures of $M$. pyogenes were grown at $25^{\circ}$ in 2 l. of casein digest medium containing $1 \%(\mathrm{w} / \mathrm{v})$ glucose and $0.1 \%$ Marmite in 5 l. rotated flasks with air exchange heads (Mitchell, 1949). The cells were harvested at a concentration equivalent to $2 \mathrm{mg}$. dry-wt./ml., washed twice with distilled water and once with the salt solution used in the assimilation experiments.

Assimilation of phosphate. The cells, prepared as described above, were suspended at a concentration equivalent to $10 \mathrm{mg}$. dry-wt. $/ \mathrm{ml}$. in a salt solution containing $5 \mu$ mole $\mathrm{Na}_{2} \mathrm{HPO}_{4}, 5 \mu$ mole $\mathrm{NaH}_{2} \mathrm{PO}_{4}, 100 \mu$ mole $\mathrm{NaCl}, 10 \mu$ mole $\mathrm{KCl}$ and $\mathbf{3 \cdot 3} \mu$ mole $\mathrm{MgCl}_{2} / \mathrm{ml}$. Two hundred ml. of the suspension was transferred to a 1 l. rotated flask with an air exchange head and allowed to equilibrate at $25^{\circ}$ for $20 \mathrm{~min}$. The inorganic phosphate of the medium was now labelled by adding sodium phosphate containing ${ }^{32} \mathrm{P}$ of total activity $c .200 \mu \mathrm{C}$. in $1 \mathrm{ml}$. of the salt solution. A reference sample of $1 \mathrm{ml}$. of the suspension was immediately withdrawn for determinations of the total $\mathbf{P}$ and ${ }^{32} \mathbf{P}$ contents per ml. of the system. At the same time as the reference sample and subsequently at suitable intervals $20 \mathrm{ml}$. samples were taken for determinations of the $\mathbf{P}$ and ${ }^{32} \mathbf{P}$ contents of the suspension medium and of the fractions of the cells.

Ninety minutes after adding the ${ }^{32} \mathbf{P}$ to the resting cell suspension, respiration or growth was initiated in different experiments by adding $10 \mathrm{ml}$. of the salt solution containing glucose to give a final concentration of $5 \%(w / v)$ or 
$10 \mathrm{ml}$. of the salt solution containing glucose and casein hydrolysate (vitaminfree casein hydrolysate of Ashe Laboratories) to give final concentrations of $5 \%$ and $1 \%(\mathrm{w} / \mathrm{v})$ respectively. The $20 \mathrm{ml}$. samples of the suspension withdrawn during the progress of assimilation were immediately centrifuged. The suspension medium was centrifuged again after decanting from the pad of cells, and $1 \mathrm{ml}$. of the clear medium was diluted for estimations of $P$ and ${ }^{32} P$, for determinations of glucose by the method of Nelson (1944) and for measurement of $\mathrm{pH}$ with a glass electrode. The $\mathrm{pH}$ value remained within the range $6 \cdot 7-7 \cdot 0$, and the concentration of glucose did not fall below $4 \cdot 8 \%$. The cells were washed three times with $20 \mathrm{ml}$. lots of distilled water, cooled in liquid air and dried over $\mathrm{P}_{2} \mathrm{O}_{5}$ in high vacuum at room temperature. Estimations of the turbidity of the washings showed that less than $1 \%$ of the cells were lost, and thus the weights of the dry cell samples could be used to measure the amount of growth.

\section{Separation of phosphate fractions}

The procedure adopted for separating the phosphate fractions of whole cells and cell components was the same as that previously described (Mitchell \& Moyle, 1951b) except that the trichloroacetic acid-soluble fraction was separated into organic and inorganic components. To $5 \mathrm{ml}$. of the acid-soluble fraction, $\mathbf{0} \cdot 1 \mathrm{ml}$. of $20 \mathrm{~N}$-ammonia and $0 \cdot 1 \mathrm{ml}$. of $5 \%(\mathrm{w} / \mathrm{v}) \mathrm{MgCl}_{2}, 5 \mathrm{H}_{2} \mathrm{O}$ were added, and the magnesium ammonium phosphate was allowed to precipitate at $2^{\circ}$ during $15 \mathrm{hr}$. The precipitate was centrifuged and washed three times with $1 \mathrm{ml}$. lots of $\mathrm{N}$-ammonia, the supernatants, containing the acid-soluble organic phosphate, being collected and made up to $10 \mathrm{ml}$. with distilled water. The precipitate, containing the inorganic phosphate, was dissolved in $0.5 \mathrm{mI}$. of $\mathrm{N}-\mathrm{HCl}$ and made up to $10 \mathrm{ml}$. with distilled water. Estimations of $\mathrm{P}$ showed that mutual contamination of $\mathrm{AI}$ and $\mathrm{AO}$ did not exceed $3 \%$.

Labile phosphate compounds occur as major components of the RNA and DNA fractions of baker's yeast (Juni et al., 1948). Using the methods of Spiegelman and his collaborators, we were unable to separate significant amounts of labile phosphate compounds from the RNA or DNA fractions of M. pyogenes. Moreover, the amounts of 'ten minute' phosphate in these fractions were too small to be distinguished from the more labile phosphate of the nucleic acids, and the amounts of DNA measured by the extinction at $260 \mathrm{~m} \mu$, using a mean mononucleotide molecular extinction coefficient of 10,000 , agreed with the amounts measured by the phosphate content to within $\pm 3 \%$. We concluded that quantities of labile phosphate compounds not exceeding $3 \%$ of the total phosphate of the RNA and DNA fractions might be present. Less than $0.1 \%$ of the phosphate of the RNA fraction occurred as inorganic phosphate, and hence the amounts of 'phosphoprotein' (Schmidt \& Thannhauser, 1945) were considered to be negligible.

Glycerophosphoprotein complex fraction. When the above fractionation procedure was carried out on whole cells, it was not possible to separate the phosphate of the RNA and PGP fractions, and consequently separate estimations of the ${ }^{32} \mathrm{P}$ contents of these fractions could not be made. It was possible, 
however, to take advantage of the fact that some 80 to $90 \%$ of the PGP can be obtained practically uncontaminated by RNA in the particulate fractions of mechanically disintegrated cells. The cells were separated into soluble and particulate (envelope + small particle) components by a method similar to that previously described (Mitchell \& Moyle, 1951 b). The distribution of $\mathbf{P}$ and ${ }^{32} \mathbf{P}$ in the cell components thus obtained from $50 \mathrm{mg}$. of dry cells was determined by the procedure applied to whole cells.

The (RNA + PGP) fraction of the particulate cell component contained less than $3 \%$ of RNA phosphate. Measurements of the $\mathbf{P}$ and ${ }^{32} \mathbf{P}$ contents of this fraction were therefore taken to represent PGP phosphate within experimental error. On the other hand, the (RNA + PGP) fraction of the soluble cell component contained about $20 \%$ of PGP phosphate, at least three-quarters of which consisted of particulate material carried over from the particulate fraction during decantation of the centrifugates. By taking precautions which were unnecessary in the routine of the present studies, the amount of PGP present in the (RNA + PGP) fraction of the soluble cell component could be diminished to less than $5 \%$. Assuming the ratio of ${ }^{82} \mathbf{P}$ to $\mathbf{P}$ estimated in the PGP of the particulate cell component represented that of the whole PGP, the ${ }^{32} \mathrm{P}$ content of the PGP of the (RNA + PGP) fraction of the soluble cell component could be estimated, and hence the total ${ }^{32} \mathrm{P}$ contents of the RNA and PGP of the cells computed.

It was necessary to consider that significant changes might occur in the $\mathbf{P}$ and ${ }^{32} \mathrm{P}$ contents of the RNA and PGP during disintegration of the cells. The 32P contents of these fractions would, for instance, be seriously affected if exchange of phosphate occurred with the AI or AO. In order to assess the extent of such changes, the $\mathbf{P}$ and ${ }^{32} \mathbf{P}$ contents of all the phosphate fractions were compared throughout an experiment corresponding to that of Table 1. Systematic differences exceeding $5 \%$ did not occur either in the $\mathbf{P}$ or ${ }^{32} \mathbf{P}$ contents of any of the fractions. In particular, the $P$ and ${ }^{32} P$ contents of the (RNA + PGP) fraction of the whole cells showed a standard deviation of only $\pm 3 \%$ from the sum of the (RNA + PGP) contents of the soluble and particulate components. Thus, all significant changes of composition during disintegration were ruled out with the possible exception of exchange of phosphate between the RNA and PGP. The fact that the ratio of ${ }^{32} \mathbf{P}$ to $\mathbf{P}$ found in the RNA and PGP varied independently during the course of phosphate assimilation (Fig. 2) showed, however, that an exchange of phosphate between these fractions might occur during disintegration only to a small extent if at all.

Estimation of total $\mathbf{P}$ and ${ }^{32} \mathbf{P}$. For determination of the total organic and inorganic phosphate contents we used micro-adaptations of the methods of Fiske \& Subbarow (1925), giving values with a standard deviation of $\pm 1 \%$ for samples containing 3 to $30 \mu \mathrm{g}$. of phosphorus.

The relative ${ }^{32} \mathrm{P}$ contents of the fractions were estimated as counts $/ \mathrm{min} . / \mu \mathrm{g} . \mathrm{P}$ in samples dried on nickel planchettes using a conventional end-window Geiger-Mueller counter and scaling unit, following the methods of Boursnell, Coombs \& Rizk (1953). Triplicate or duplicate samples were taken for each 
determination and at least 1000 counts were registered for each sample. With every group of ten samples, the count given by the reference sample was redetermined so that corrections could be made for periodic changes in the efficiency of the counting machinery and for decay of the ${ }^{32} \mathrm{P}$. The standard deviation of the ${ }^{32} \mathrm{P}$ measurements was $c . \pm 5 \%$.

Indices of phosphate contents. The specific activities as counts $/ \mathrm{min} . / \mu \mathrm{g} . \mathbf{P}$ were converted to relative specific activities (or relative specific ${ }^{32} \mathbf{P}$ contents), $\boldsymbol{R}$, defined as $R=k \cdot{ }^{32} \mathrm{P} / \mathrm{P}$, the constant $k$ being fixed to give $R=1$ for the ratio of ${ }^{32} \mathbf{P}$ to $\mathbf{P}$ in the whole system. It is usual to define the unit of relative specific activity with reference to the specific activity of the medium. The definition of $\boldsymbol{R}$ used here has the advantage of showing the equilibration of all the phosphate fractions, including the medium, as an ultimate movement of $R$ towards unity.

The product of the relative specific ${ }^{32} \mathbf{P}$ content and the $\mathbf{P}$ content of a fraction is proportional to the ${ }^{32} \mathrm{P}$ content, i.e. $R . \mathrm{P}=k \cdot{ }^{32} \mathrm{P}, k$ being the same as before. Since $k$ is defined as the ratio of $\mathbf{P}$ to ${ }^{32} \mathbf{P}$ for the whole system, the sum of the $k .{ }^{32} \mathrm{P}$ contents of all the phosphate fractions should be equal to the total $\mathbf{P}$ content of the system-a valuable property for checking the reliability of the ${ }^{32} \mathrm{P}$ estimations. We shall express the quantities of $\mathrm{P}$ as $\mu \mathrm{mole} / \mathrm{g}$. cell dry-weight, written $\mu$ mole/g.

Definition of turnover. Several patterns of phosphate transfer, which might loosely be called turnover, occurred in the present experiments. It will be convenient to consider two of them at this point.

We shall reserve the word turnover to describe the strictly reciprocal exchange of phosphate between two fractions, for it was mainly in this sense that the word was originally used by Schoenheimer (1942). To calculate the rate of turnover of phosphate $(\dot{\mathrm{P}})$ between fractions $A$ and $B$, considered as a closed system, from the time of half equilibration of ${ }^{32} \mathbf{P}\left(t_{1}\right)$ the following expression (Mitchell, 1953) will be used: $\dot{\mathrm{P}}=\left(\log _{e} 2\right) \cdot \mathrm{P}_{A} \cdot \mathbf{P}_{B} /\left(\mathbf{P}_{A}+\mathbf{P}_{B}\right) \cdot t_{\mathrm{b}}$, the symbols $\mathbf{P}_{A}$ and $\mathbf{P}_{B}$ representing the total phosphate contents of fractions $A$ and $B$.

Precursor-product relationship. In the commonest pattern of transfer resembling turnover, the phosphate passes from a fraction $X$, through a fraction $Y$ to a fraction $Z$, the phosphate of fraction $Y$ exhibiting a false turnover. In general, this precursor-product type of pattern may be distinguished from turnover by comparing the observed change of the $k{ }^{32} \mathrm{P}$ content of fraction $Y$ with the change of the $k .{ }^{32} \mathrm{P}$ content calculated from an integrated form of principle (iii). The integrated form of principle (iii) is simply a continuity equation which may be written:

$$
\Delta\left(k .{ }^{32} \mathbf{P}_{Y}\right)=\int_{t_{1}}^{t_{2}} R_{X} d \mathbf{P}_{X \rightarrow Y}-\int_{t_{1}}^{t_{2}} R_{Y} d \mathbf{P}_{Y \rightarrow Z},
$$

or in words: the accumulation of $k .{ }^{32} \mathrm{P}$ in fraction $Y$ during the time $\left(t_{2}-t_{1}\right)$ is the integral of the $R$ value of fraction $X$ with respect to the flow of $P$ from $\boldsymbol{X}$ to $\boldsymbol{Y}$ minus the integral of the $R$ value of fraction $\boldsymbol{Y}$ with respect to the flow of $P$ from $Y$ to $Z$. In practice the calculation is made by summing the products 
of the mean $R$ values and the $P$ fluxes over the series of short time intervals between the collection of cell samples. This method of integration is, of course, approximate, but in the present experiments, the errors introduced were found, by comparison with graphical integration, to be of the same order as the experimental errors.

\section{RESULTS}

\section{Cell suspension without added substrate}

During the $90 \mathrm{~min}$. of so-called rest in the absence of added substrate (Fig. 1), the $R$ values of the AI, AO and LP rise and that of the mI falls; but the $R$ values of the other fractions do not change significantly. The changes in the $R$ values of the AI, AO, LP and $\mathrm{mI}$ might be due either to a reciprocal exchange of phosphate between the fractions or to transfer processes energized by the residual metabolism which occurs in washed suspensions of this organism.

\section{Exchange of inorganic phosphate between cells and medium}

Table 1 shows that during the period of rest, neither the $\mathbf{P}$ content of the cells nor of the medium change significantly, but a total of $150 \mu \mathrm{mol} . k{ }^{32} \mathrm{P} / \mathrm{g}$. are taken up, of which $91 \%$ is accounted for in the AI. Thus, although there is no net transfer, there is an exchange of inorganic phosphate between the cells and medium which is half complete in $c .70 \mathrm{~min}$. This gives a rate of turnover of phosphate between the AI and $\mathrm{mI}$ of $1.4 \mu \mathrm{mole} / \mathrm{g} . / \mathrm{min}$.

Although during the period of rest the rise in the $R$ value of the AI may be attributed to a reciprocal exchange of phosphate with the $\mathrm{mI}$ without change of free energy, the rise in the $R$ value of the AO cannot be accounted for in this way. The $\mathbf{P}$ content of the AO rises by $16 \mu \mathrm{mole} / \mathrm{g}$. during the resting period (Table 1), and assuming this phosphate to be supplied via the AI (see below) which has a mean $R$ value of $c .0 \cdot 6$ over this period (Fig. 1), the amount of $k \cdot{ }^{32} \mathrm{P}$ accumulating in the AO would be $16 \times 0 \cdot 6=9 \cdot 6 \mu \mathrm{mole} / \mathrm{g}$. The observed increment of $k .{ }^{32} \mathrm{P}$ in the $\mathrm{AO}$ is $14 \mu \mathrm{mole} / \mathrm{g}$., and since this may be too high by as much as $3 \mu \mathrm{mole} / \mathrm{g}$. because of contamination of $\mathrm{AO}$ with $3 \%$ of $\mathrm{AI}$, the observed increment is within experimental error of the calculated figure. The rise in the $R$ value of the AO in the absence of added substrate may therefore be attributed mainly to the uptake of phosphate into the AO energized by residual metabolism. The data of Table 1 indicate that the rise in the $R$ value of the LP might also be attributed partly to an active uptake of phosphate.

\section{Cell suspension with glucose}

During respiration caused by the addition of glucose to the cell suspension, the $R$ values of AI, AO and LP (Fig. 1, continuous lines) approach that of $\mathrm{mI}$ more rapidly than during rest, and the $R$ values of PGP, DNA and RNA (Fig. 2, continuous lines) show small but significant increases. The fact that the $P$ content of the DNA remains constant shows that there is no net increase in cell numbers, for it was previously found that the amount of DNA per cell remained constant during growth (Mitchell \& Moyle, 1951 a). Multiplication might, however, occur if accompanied by an equal rate of autolysis. The 
observed $\boldsymbol{R}$ increments could have resulted from the lysis and growth of only c. $1 \%$ of the cells per hour. We cannot therefore tell whether the small changes in the $R$ values of the PGP, DNA and RNA are due to the utilization of the glucose per se, or whether they are due to growth of some of the cells on the

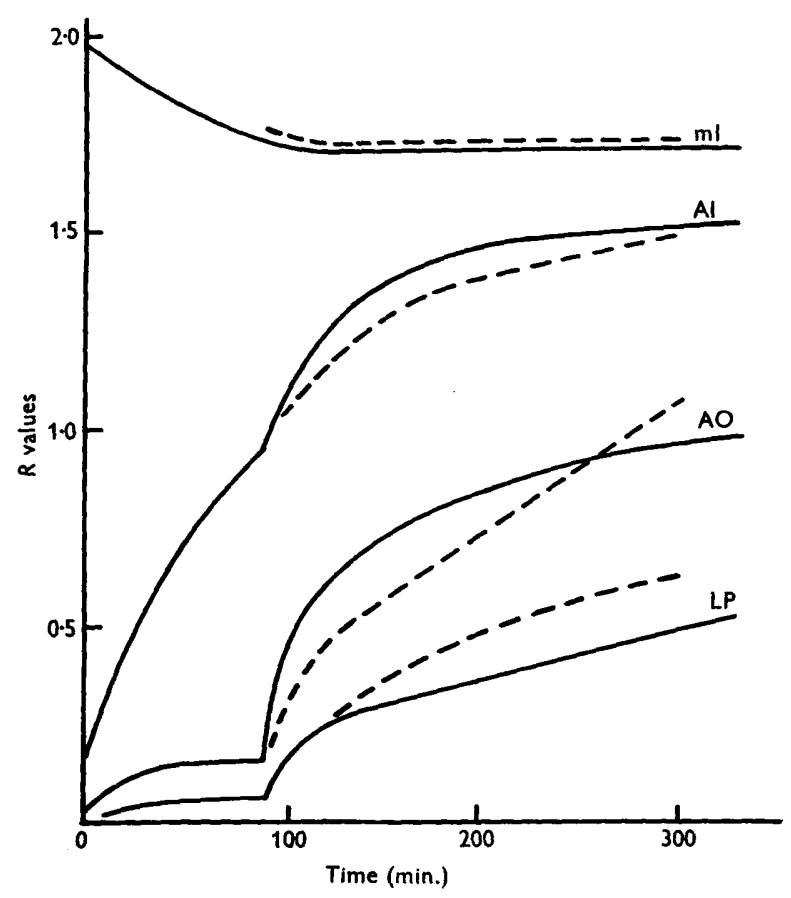

Fig. 1. The time course of the $R$ values of the $\mathrm{mI}, \mathrm{AI}, \mathrm{AO}$ and LP. Cell suspension resting (0 to $90 \mathrm{~min}$.), respiring (continuous lines, 90-330 min.) and growing (broken lines, 90-300 min.). The lines represent the $R$ values taken from Tables 1 and 2.

Table 1. The k ${ }^{32} \mathrm{P}$ and $\mathrm{P}$ contents of the phosphate fractions from $\mathrm{M}$. pyogenes during rest and respiration

Cell

me dry-wt.

n.) (mg./ml.)

$\begin{array}{rr}0 & 10 \cdot 0 \\ 30 & 10 \cdot 0\end{array}$

$10 \quad 10 \cdot 0$

$\begin{array}{ll}\mathbf{3} & 10 \cdot 0 \\ 4 & 10 \cdot 0 \\ 6 & 10 \cdot 0 \\ 0 & 10 \cdot 0 \\ 0 & 10 \cdot 0\end{array}$

Fractions

\begin{tabular}{|c|c|c|c|c|c|c|c|}
\hline $\mathbf{m I}$ & $\mathbf{A I}$ & AO & $\mathbf{L P}$ & DNA & RNA & PGP & Total \\
\hline \multicolumn{8}{|c|}{$\mu$ mole $k .{ }^{32} \mathrm{P}$ and $\mathrm{P} / \mathrm{g}$. initial cell dry-wt., written $k{ }^{32} \mathrm{P} / \mathrm{P}=R$} \\
\hline $880 / 850$ & $28 / 164$ & $3 \cdot 1 / 100$ & $0 \cdot 3 / 45$ & $0 \cdot 1 / 74$ & $0 \cdot 2 / 258$ & $0.5 / 232$ & $1712 / 1723$ \\
\hline $300 / 850$ & $89 / 165$ & $12 \cdot 7 / 106$ & $1 \cdot 4 / 46$ & $0 \cdot 2 / 80$ & $0.6 / 258$ & $1 \cdot 7 / 245$ & $1706 / 1750$ \\
\hline $110 / 850$ & $164 / 171$ & $17 \cdot 2 / 116$ & $2 \cdot 6 / 48$ & $0 \cdot 3 / 80$ & $1 \cdot 3 / 254$ & $2 \cdot 2 / 236$ & $1698 / 1755$ \\
\hline
\end{tabular}

Glucose added at $90 \mathrm{~min}$. to give $5 \%(\mathrm{w} / \mathrm{v})^{*}$

$\begin{array}{llrrrrrr}1620 / 950 & 209 / 174 & 70 / 122 & 10 \cdot 4 / 50 & 1 \cdot 6 / 77 & 7 \cdot 7 / 253 & 7 \cdot 9 / 245 & 1927 / 1871 \\ 1570 / 910 & 242 / 181 & 93 / 142 & 16 \cdot 7 / 60 & 2 \cdot 3 / 75 & 7 \cdot 5 / 245 & 15 \cdot 0 / 273 & 1946 / 1886 \\ 1440 / 860 & 278 / 200 & 119 / 161 & 20 \cdot 7 / 63 & 2 \cdot 8 / 80 & 10 \cdot 1 / 241 & 21 \cdot 1 / 268 & 1892 / 1873 \\ 1320 / 770 & 353 / 226 & 155 / 181 & 26 \cdot 1 / 68 & 3 \cdot 3 / 77 & 9 \cdot 8 / 246 & 26 \cdot 3 / 263 & 1893 / 1831 \\ 1120 / 650 & 413 / 280 & 227 / 235 & 37 / 71 & 3 \cdot 7 / 81 & 9 \cdot 7 / 248 & 40 / 267 & 1850 / 1832\end{array}$

This solution contained the equivalent of $100 \mu$ mole ${ }^{31 P}$ : it affects the total $k .{ }^{32 P}$ and $P$ correspondingly. 
nitrogenous autolysis products of others. On the other hand, there is little doubt that the relatively large increases in the $\mathbf{P}$ and $k{ }^{32} \mathbf{P}$ contents of the AI, AO and LP may be attributed to the utilization of glucose.

Uptake of inorganic phosphate. During respiration, the cells take up $\mathbf{P}$ at the rate of $c .1 \cdot 4 \mu \mathrm{mole} / \mathrm{g}$. $/ \mathrm{min}$. (Table 1 ) while the $R$ value of the $\mathrm{mI}$ remains constant (Fig. 1). Thus, the movement of phosphate from the medium to the cells occurs at the same rate as during rest, but the equal and opposite movement of phosphate which occurs during rest is abolished.

Intermediary function of $A I$. Although, as shown above, there is no turnover of phosphate between the $\mathrm{mI}$ and AI during respiration, the $k \cdot{ }^{32} \mathrm{P}$ and $\mathbf{P}$ contents of the $\mathrm{AI} / \mathrm{g}$. increase by 249 and $109 \mu$ mole respectively. The $R$ value of the $\mathrm{mI}$ remains within experimental error of the constant value $1 \cdot 71$ after the sample taken at $90 \mathrm{~min}$. The increment of $k .{ }^{32} \mathrm{P}$ which would result simply from the accumulation of phosphate in the AI is therefore $1.71 \times 109=186 \mu \mathrm{mole} / g$., significantly below the observed value. Another possibility is that the phosphate of all the organic fractions may be drawn through the AI. In this case, since the amount of $P$ entering the AI would be the sum of that entering all the fractions, and the amount leaving would be the same less that accumulating in the AI, and since the $R$ values of the $\mathrm{mI}$ and $\mathrm{AI}$ are known, the $k .{ }^{32} \mathrm{P}$ content of the AI may be calculated as described above for the precursor-product system. The value of $242 \mu \mathrm{mole} / \mathrm{g}$. thus obtained is within experimental error of the observed amount. However, if only half the phosphate of the other fractions were drawn through the AI, we would consider the calculated value, $214 \mu \mathrm{mole} k .{ }^{32} \mathrm{P} / \mathrm{g}$. to lie only just significantly below the observed increment. The uptake of ${ }^{32} \mathrm{P}$ into the AI may therefore be explained if the greater part, but not necessarily all, of the phosphate of the other fractions is drawn through the AI. We should point out that the application of principle (iii) is probably legitimate in this case because the AI is unlikely to be unhomogeneous with respect to ${ }^{32} \mathrm{P}$ content.

Accumulation of phosphate in $A O$. During respiration, the $k .{ }^{32} \mathrm{P}$ increment of the AO, calculated from the observed accumulation of $P$ assumed to come from the AI, is 168 while the observed $k .{ }^{32} \mathrm{P}$ increment of the $\mathrm{AO}$ is $210 \mu \mathrm{mole} / \mathrm{g}$. Evidently, therefore, a limited amount of turnover occurs between the AI and AO. It should be noted that during respiration, although a small but significant accumulation of $P$ occurs in the LP and PGP, there is no $P$ accumulation in the DNA or RNA. Of the total $P$ taken up by the cells, c. $90 \%$ accumulates in the $\mathrm{AI}$ and $\mathrm{AO}$.

\section{Cell suspension with glucose and nitrogen source}

The addition of glucose and casein hydrolysate to the washed cell suspension causes growth at the rate of $c .2 \mathrm{mg} . / \mathrm{ml}$./ hr. (Table 2 ). The rate of increase of the $P$ content of the DNA, and therefore the rate of increase in cell numbers, is approximately half that of cell dry-weight, the average weight per cell increasing by a factor of 1.2 during the experiment of Table 2.

During growth, the $R$ values of the $\mathrm{mI}, \mathrm{AI}, \mathrm{AO}$ and LP (Fig. 1, broken lines) show practically the same pattern of change as during respiration; but the $R$ 
values of the PGP, RNA and DNA increase more rapidly than during respiration (Fig. 2).

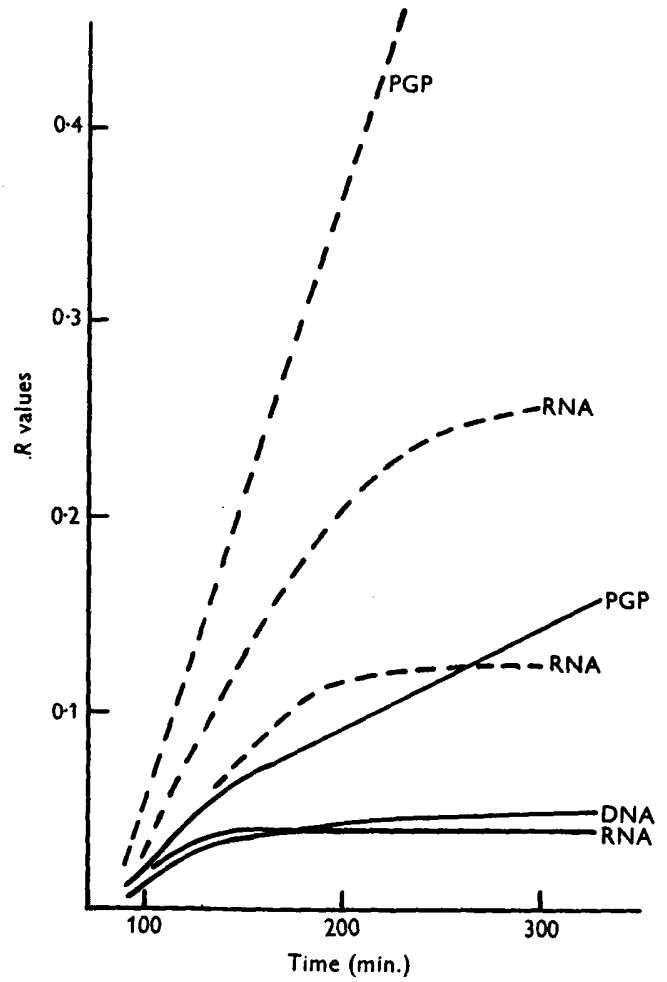

Fig. 2. The time course of the $R$ values of the DNA, RNA and PGP. Cell suspension respiring (continuous lines) and growing (broken lines). The lines represent the $\boldsymbol{R}$ values taken from Tables 1 and 2.

Table 2. The $k \cdot{ }^{32} \mathrm{P}$ and $\mathbf{P}$ contents of the phosphate fractions during growth

Fractions

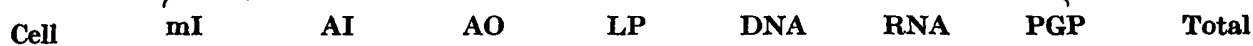

ime dry-wt.

nin.) (mg./ml.)

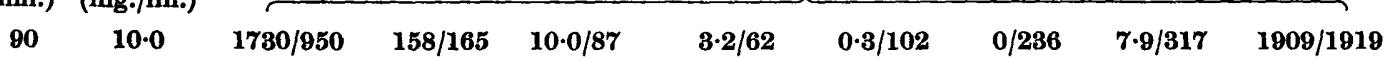

Glucose and casein hydrolysate added at $90 \mathrm{~min}$. to give $5 \%$ and $1 \%(\mathrm{w} / \mathrm{v})$ respectively*

$\begin{array}{rrrrrrrrrr}180 & 11.5 & 1630 / 980 & 192 / 155 & 46 / 93 & 16 \cdot 8 / 62 & 10 \cdot 4 / 113 & 13 \cdot 4 / 251 & 50 / 341 & 1959 / 1995 \\ 195 & 13 \cdot 5 & 1540 / 880 & 235 / 174 & 68 / 103 & 29 \cdot 4 / 64 & 24 \cdot 4 / 124 & \mathbf{3 7} / 313 & 133 / 367 & 2067 / 2025 \\ 100 & 15 \cdot 4 & 1290 / 780 & 255 / 171 & 152 / 136 & 44 / 73 & 33 / 131 & 40 / 321 & \mathbf{2 5 0} / 445 & 2064 / 2047\end{array}$

This solution contained the equivalent of $100 \mu$ mole of ${ }^{31 P}$ : it affects the total $k .{ }^{32 P}$ and P correspondingly.

Uptake of inorganic phosphate. The rate of intake of $\mathbf{P}$ by the cells during growth (Table 2) does not differ from that during rest (1.3 as opposed to 1.4 $\mu \mathrm{mole} / \mathrm{g}$./min.) by more than the variation between different batches of 
resting cells, and the $R$ value of the $\mathrm{mI}$ remains constant. Presumably the same system causes the uptake of phosphate in growing as in respiring cells.

Intermediary function of $A I$. The increase in the $\mathbf{P}$ content of the AI during growth is relatively small (6 $\mu$ mole/g.), and, calculating the $k .^{32} \mathrm{P}$ increments from the $90 \mathrm{~min}$. sample and taking the $R$ value of the $\mathrm{mI}$ as 1.72 , accounts for only $10 \cdot 3 \mu \mathrm{mole} / \mathrm{g}$. of the observed $k .{ }^{32} \mathrm{P}$ increment of $97 \mu \mathrm{mole} / \mathrm{g}$. Assuming, as for the respiring suspension, that the phosphate of all the other fractions is drawn through the AI, a $k .{ }^{32} \mathrm{P}$ increment of 131 is obtained, significantly above the observed increment. This corresponds to a total passage of $300 \mu$ mole of $P$ and $400 \mu$ mole of $k .{ }^{32} \mathrm{P} / \mathrm{g}$. through the AI, whereas the observed course of the $k .{ }^{32} \mathrm{P}$ content of the AI would correspond to $c .220 \mu$ mole $\mathbf{P}$ and $300 \mu$ mole $k .{ }^{32} \mathrm{P} / \mathrm{g}$. The following alternative explanations may account for these observations:

(i) About $70 \%$ of the phosphate of the organic fractions may be drawn through the AI and the remaining $30 \%$ either from the $\mathrm{mI}$ or from the unknown carrier compound of the exchange diffusion system (see below). If this were the case, the part drawn through the AO would account for $300 \mu$ mole $k{ }^{32} \mathrm{P} / \mathrm{g}$., and the part from the $\mathrm{mI}$ (or carrier compound) would account for $(300-200) \times 1 \cdot 72=138$, giving a total of $438 \mu$ mole $k .{ }^{32} \mathrm{P} / \mathrm{g}$. This figure is consistent with the $490 \mu$ mole found to enter the organic fractions (Table 2), considering that the calculated $k .{ }^{32} \mathrm{P}$ contents are small differences between large quantities.

(ii) The whole of the phosphate of the organic fractions may be drawn through the AI while a turnover of phosphate involving the interchange of c. $150 \mu$ mole phosphate, occurs between the AI and one or more of the organic fractions. At all events, at least $60 \%$ of the phosphate of the organic fractions must be drawn through the AI.

Origin of $R N A$ phosphate. The total amounts of $k .{ }^{32} \mathrm{P}$ and $\mathrm{P}$ taken up by the RNA during growth are 40 and $85 \mu \mathrm{mole} / \mathrm{g}$. respectively, giving an apparent mean $R$ value for the accumulated phosphate of less than $\mathbf{0 . 5}$. It is therefore probable that the bulk of the phosphate of the RNA could not originate from the mI or AI. Assuming that the AO were to supply the phosphate of the RNA, the total $k .{ }^{32} \mathrm{P}$ uptake by the RNA (estimated from the $R$ values of the AO and the $P$ increments of the RNA) would be $47 \mu$ mole/g., in reasonably good agreement with the observed value. It should be emphasized that the AO (consisting mainly of a mixture of nucleotide components) may be assumed to be heterogeneous with respect to ${ }^{32} \mathrm{P}$ content, the $\boldsymbol{R}$ values given here being indices of the mean $k .{ }^{32} \mathrm{P} / \mathrm{P}$ ratio for all the components. Consequently the results of the application of the precursor-product relationship should be accepted with obvious reservations. This does not, however, invalidate the fact that the $k \cdot{ }^{32} \mathrm{P}$ content of the RNA behaves as though the components of the AO were incorporated directly into the RNA. Moreover, it is certain that little or no turnover of the phosphate of the RNA can occur with any of the more metabolically active (and therefore ${ }^{32} \mathrm{P}$ rich) fractions during growth.

Origin of DNA phosphate. The total amounts of $k .{ }^{32} \mathrm{P}$ and $\mathrm{P}$ taken up by the DNA during growth are 33 and $29 \mu$ mole/g. respectively, giving an apparent 
mean $R$ value for the accumulated phosphate of $1 \cdot 14$. It is therefore probable that the bulk of the phosphate of the DNA could not originate from the mI. If the AI were to supply the phosphate of the DNA without turnover, the total $k$. ${ }^{32} \mathrm{P}$ uptake by the DNA (estimated as for the RNA) would be $36 \mu \mathrm{mole} / \mathrm{g}$., within experimental error of the observed value of 33. If, on the other hand, the AO were to supply the phosphate of the DNA, the total $k \cdot{ }^{32} \mathrm{P}$ uptake would be $16 \mu \mathrm{mole} / \mathrm{g}$., and to account for the observed value of 33 , about one DNA phosphate group would have to exchange with the AO for each new DNA phosphate group taken up.

Intermediary function of $A O$. During growth, the $k .{ }^{32} \mathrm{P}$ increment of the $\mathrm{AO}$, calculated for the observed accumulation of $\mathbf{P}$ assumed to come from the AI is $67 \mu \mathrm{mole} / \mathrm{g}$., much more divergent from the observed $k .{ }^{32} \mathrm{P}$ increment (142 $\mu$ mole/g.) than was the case during respiration. However, the situation during growth differs from that during respiration in that $\mathbf{P}$ accumulates in the RNA, DNA and PGP. Assuming that the P entering the RNA is drawn from the AI, through the AO, the $k .{ }^{32} \mathrm{P}$. increment of the $\mathrm{AO}$ (calculated from the $R$ values of the $A I$ and $A O$ and the increments of the $P$ of the $A O$ and RNA) is $127 \mu$ mole/g., within experimental error of the observed value. Alternatively, assuming that the $\mathrm{AO}$ is similarly the intermediate for formation of both RNA and DNA, a $k .{ }^{32} \mathrm{P}$ increment of $147 \mu \mathrm{mole} / \mathrm{g}$. is obtained, also within experimental error of the observed value. If, however, the $P$ entering all the other fractions were to pass from the $\mathrm{AI}$, through the $\mathrm{AO}$, the $k{ }^{32} \mathrm{P}$ increment would be $200 \mu \mathrm{mole} / \mathrm{g}$., above the experimental value.

During a separation of the AO into free purine, total purine and total pyrimidine (Mitchell \& Moyle, $1951 a$ and unpublished observations), it was found that at least $80 \%$ of the phosphate of the $\mathrm{AO}$ was present in purine and pyrimidine pentose nucleotides, the ease of hydrolysis of the purine nucleotides indicating that they were largely of the purine-3-P type (Caldwell, 1951). The amount of ester phosphate hydrolysed by $\mathrm{N}-\mathrm{HCl}$ in $10 \mathrm{~min}$. at $100^{\circ}$, after correction for purine nucleotide phosphate was only 10 to $15 \%$ of the total phosphate in different samples, and probably consisted of a mixture of ribose-1-P and nucleotide pyrophosphate phosphorus. No deoxypentose could be detected in the AO by the method of Dische (1930).

We consider it probable, therefore, that the bulk of the AO phosphate consists of the nucleotide precursors of the RNA; that the phosphate of the DNA is drawn from the AI either directly or through intermediates present in small amount in the AO; and that like the RNA phosphate, the DNA phosphate exchanges little if at all with the more metabolically active phosphate fractions. The possibility that the bulk of the phosphate of the DNA could be derived from the RNA or vice versa is absolutely ruled out.

Origin of the PGP phosphate. The total amounts of $k .{ }^{32} \mathrm{P}$ and $\mathrm{P}$ taken up by the PGP during growth are 242 and $128 \mu$ mole/g., respectively, giving an apparent mean $R$ value of $\mathbf{1 . 8 6}$ for the accumulated phosphate. It was shown above that the $k \cdot{ }^{32} \mathrm{P}$ content of the AI indicated that either 30 to $40 \%$ of the phosphate entering the organic fractions during growth is drawn direct from the $\mathrm{mI}$ or a turnover involving the interchange of $c .150 \mu$ mole phosphate/g. 
occurs between the AI and one or more of the organic fractions. Of the total $\mathbf{P}$ accumulated by the organic fractions $c .55 \%$ is accounted for by uptake without turnover into the AO, RNA and DNA via the AI. The PGP is responsible for $c .40 \%$ of the $P$ uptake.

If the phosphate of the PGP were drawn direct from the $\mathrm{mI}$ without turnover, the amount of $k .{ }^{32} \mathrm{P}$ entering the PGP would be $204 \mu \mathrm{mole} / \mathrm{g}$., in agreement with the observed value of 242 ; whereas, if the phosphate were similarly drawn from the AI, the amount of $k .{ }^{32}$ P entering the PGP would be 153 . Thus, the PGP phosphate might be drawn either direct from the $\mathrm{mI}$ (or the carrier compound of the exchange diffusion system) without significant turnover, or via the AI with a turnover corresponding to the exchange of one phosphate group for every two phosphate groups entering the PGP.

Origin of the $L P$ phosphate. The total amounts of $k .{ }^{32} \mathrm{P}$ and $\mathrm{P}$ taken up by the LP during growth are 41 and $11 \mu \mathrm{mole} / \mathrm{g}$., respectively, giving an apparent mean $R$ value of 3.7 for the accumulated phosphate. The LP accounts for less than $5 \%$ of the total $P$ uptake by the organic fractions, and, as with the PGP, it is not possible to determine whether the phosphate is taken up directly from the $\mathrm{mI}$ or via the AI. It is, however, evident that the LP shows the highest unequivocal turnover whether it be with the $\mathrm{mI}$ or $\mathrm{AI}$.

\section{DISCUSSION}

The exchange of 'inorganic phosphate' between resting cells and their suspension medium might be attributed either to exchange adsorption, proposed by Roberts \& Roberts (1950), or to a type of mechanism first described by Lundegårdh (1945) and later named exchange diffusion by Ussing (1947). The importance of making a decision between these hypotheses has led one of us to study the characteristics of the exchange reaction in detail. The first results of this study (Mitchell, 1953) show that the osmotic barrier of $M$. pyogenes is impermeable to phosphate ions and that the movement of phosphate groups across the osmotic barrier is regulated by an exchange diffusion system.

Since the rate of intake of inorganic phosphate during respiration is the same as the rate of exchange across the osmotic barrier during rest, we suggest that the same system is responsible for both processes, and that during respiration a source of free energy is made available to do the necessary osmotic work.

Labaw, Mosley \& Wyckoff (1950) and Roberts \& Roberts (1950) found that very little ${ }^{32} \mathbf{P}$ is lost from growing suspensions of Bacterium coli when transferred from a medium containing ${ }^{32} \mathrm{P}$-labelled phosphate to a ${ }^{32} \mathrm{P}$-free medium. Caldwell, Mackor \& Hinshelwood (1950) made a similar observation on Aerobacter aerogenes and concluded that '... while the nucleic acid is actually participating in the synthesis of protein, little of its phosphorus undergoes exchange...' We have shown, however, that in $M$. pyogenes, during respiration or growth, phosphate groups pass only inwards through the osmotic barrier. Hence, the demonstration that phosphate $\left({ }^{32} \mathrm{P}\right)$ fails to pass out of an organism into the medium during growth cannot be taken to show that the phosphate of the RNA or DNA does not turn over with other phosphate com- 
pounds inside the cells. Nevertheless, we have obtained some experimental support for the view that during growth the RNA and DNA phosphate exchanges little if at all in $M$. pyogenes.

According to Spiegelman and his collaborators (Juni et al. 1948), a turnover of phosphate occurs in the nucleic acid of baker's yeast during growth; and phosphate turnover has also been reported for the RNA and DNA of Proteus vulgaris by Levy, Scutch \& Schade (1949). The meaning attached to the word turnover by these authors appears, however, to be rather a loose one. An examination of the experimental data indicates that neither in baker's yeast nor in $\boldsymbol{P}$. vulgaris has a significant reciprocal exchange of phosphate between the nucleic acids and any other phosphate fraction been demonstrated during growth.

The DNA of $M$. pyogenes resembles that of mammalian tissue cells in exhibiting little or no phosphate turnover; whereas the lack of RNA phosphate turnover in $M$. pyogenes is in contradistinction to the behaviour reported for the RNA of mammalian tissue cells (e.g. Brues, Tracy \& Cohn, 1944; Furst, Roll \& Brown, 1950).

A point which does not generally seem to be recognized when considering low turnover values is that a cell suspension differs qualitatively from a single cell because it may exhibit a false type of turnover due to simultaneous lysis and regeneration of cells. A similar false turnover may also be given by tissues in which the cells or their sub-units absorb precursor substances and release their products.

In stating that the turnover of the phosphate of the RNA and DNA is not a necessary accompaniment of the processes of synthesis described as growth, we do not wish to imply that the nucleic acids take no part in the synthetic processes. On the contrary, the stability of the nucleic acids in the cells would seem to be in accord with the controlling function which has often been attributed to them.

The formation of DNA from RNA, originally considered by Brachet (1933) and shown to be unlikely by Schmidt, Hecht \& Thannhauser (1948) and by Villee, Lowens, Gordon, Leonard \& Rich (1949) has been considered again by Caldwell \& Hinshelwood $(1950,1951)$. The evidence of the present work is against transfer of phosphate between the bulk of the RNA and DNA either directly or indirectly. The observations that phage DNA synthesis in Bact. coli occurs at the expense of the DNA phosphate (Koch, Putnam \& Evans, 1952), but not at the expense of the host RNA phosphate (Cohen, 1951), likewise shows that in phage infected Bact. coli a transfer of phosphate from the RNA to DNA does not occur. We have also been informed by J. D. Watson that in unpublished work employing ${ }^{32} \mathbf{P}$, he has found no transfer of phosphate either from RNA to DNA or vice versa in normal growing cultures of Bact. coli.

Our conclusions as to the pathway of the phosphate which goes to form RNA and DNA during growth of $M$. pyogenes can best be described diagrammatically (see Fig. 3).

The phosphate required for the formation of the glycerophosphoprotein complex and the phospholipid originates from the inorganic phosphate either 
of the external medium or of the cell interior. Had the PGP or LP been situated only inside the osmotic barrier, a decision between these alternatives would have been possible. Unfortunately, however, both the PGP and LP form a substantial part of the cell envelope (Mitchell \& Moyle, 1951 b) and are probably accessible to both internal and external media.

It was thought at the outset of the present work that the PGP, being the predominant phosphate ester of the cell envelope, might be the intermediate by which phosphate was transferred from the medium to the cell interior. However, the PGP as a whole cannot be the postulated intermediate because

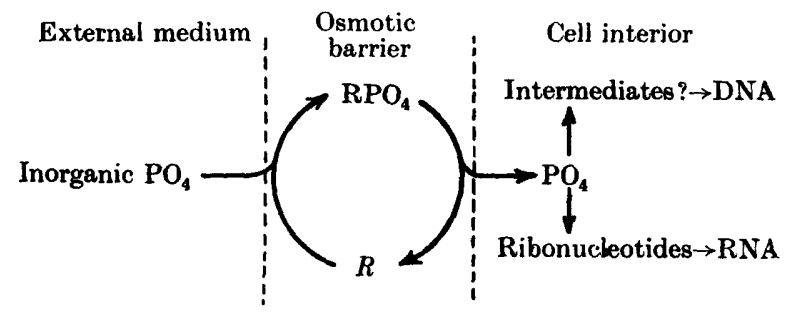

Fig. 3

it does not exhibit a significant turnover in resting cell suspensions in which a rapid exchange of inorganic phosphate occurs. It is also evident that the PGP is not involved in the phosphate transfer reactions associated with respiration since the PGP phosphate exhibits little or no true turnover in respiring suspensions. During growth, however, while the number of cells (DNA phosphate) increased by a factor of 1.29 the cell dry-weight increased by a factor of 1.55 and the PGP by a factor of 1.41 . Hence the average weight per cell increased by a factor of $1 \cdot 20$ and, as the cells do not change their shape or density appreciably during growth, the average area per cell must have increased by a factor of $(1 \cdot 20)^{\frac{3}{3}}=1 \cdot 13$. The total cell area must therefore have increased by a factor of $1 \cdot 13 \times 1 \cdot 29=1 \cdot 46$-within the experimental error of the observed PGP increase. Thus, the PGP production and cell area expansion occur at the same rate in accordance with the fact that the mechanically resistant part of the cell envelope of $M$. pyogenes is composed of PGP.

It might be expected that the closely associated PGP and LP would have a common phosphate metabolism, especially as the phosphate is present in both as glycerol esters. But, while the PGP and LP may have a common glycerophosphate precursor, the accessibility of the phosphate of the LP for exchange is evidently much greater than that of the PGP.

As a whole, our observations lead to the conclusion that most of the organic phosphate compounds of the cells of $M$. pyogenes do not exchange their phosphate groups at a rate comparable to that of phosphorylation during growth. In other words, the enzymes catalysing the formation of the phosphate compounds do not catalyse their interchange at a comparable rate. It follows that the reactions causing the synthesis of the organic phosphate compounds do not normally take place near equilibrium. 


\section{Phosphate transfer in Micrococcus pyogenes}

We are indebted to Dr J. Boursnell for allowing us to use his counting machinery to estimate ${ }^{32}$ P. One of us (J.M.M.) wishes to acknowledge the receipt of a grant from the Medical Research Council in support of this work.

\section{REFERENCES}

Boursnelu, J. C., Coombs, R. R. \& Rizk, V. (1953). Studies with marked antisera. Biochem. $J$. In the press.

BracheT, J. (1933). Recherches sur le synthèse de l'acide thymonucléique pendant le développement de l'œuf d'oursin. Arch. Biol., Paris, 44, 519.

Brues, A. M., Tracey, M. M. \& Cohn, W. E. (1944). Nucleic acids of rat liver and hepatoma: their metabolic turnover in relation to growth. J. biol. Chem. 155, 619.

Caldwell, P. C. (1951). The nature of the phosphorus compounds present in cells of Bact. lactis aerogenes. J. chem. Soc. p. 166.

Caldwell, P. C. \& Hinshelwood, C. (1950). Some considerations on autosynthesis in bacteria. J. chem. Soc. p. 3156.

Caldwell, P. C. \& Hinshelwood, C. (1951). The phosphorus metabolism of Bact. lactis aerogenes. J. chem. Soc. p. 158.

Caldwell, P. C., Mackor, E. L. \& Hinshelwood, C. (1950). The ribose nucleic acid content and cell growth of Bact. lactis aerogenes. J. chem. Soc. p. 3151.

CoHEn, S. S. (1951). Biochemical studies on multiplication of bacterial viruses. Fed. Proc. 10, 585.

Discre, Z. (1930). Über einige neue characteristische Farbreaktionen der Thymonucleinsäure und eine Mikromethode zur Bestimmung derselben in tierischen Organen mit Hilfe dieser Reaktionen. Mikrochemie, 8, 4.

Fiske, C. H. \& Subbarow, Y. (1925). The colorimetric determination of phosphorus. J. biol. Chem. 66, 375.

Furst, S. S., Roll, P. M. \& Brown, G. B. (1950). On the renewal of the purines of the desoxypentose and pentose nucleic acids. J. biol. Chem. 183, 251.

Juni, E., Kamen, M. D., Reiner, J. M. \& Spiegelman, S. (1948). Turnover and distribution of phosphate compounds in yeast metabolism. Arch. Biochem. 18, 387.

Koch, A. L., Putnam, F. W. \& Evans, E. A. (1952). Biochemical studies of virus reproduction. VIII. Purine metabolism. J. biol. Chem. 197, 113.

LABaw, L. W., Mosley, V. M. \& WyCkofF, R. W. G. (1950). Radioactive studies of the phosphorus metabolism of Escherichia coli. J. Bact. 59, 251.

Levy, H. B., Skutch, E. T. \& Schade, A. L. (1949). Effect of cobalt on the phosphorus turnover rate in the nucleic acids of Proteus vulgaris. Arch. Biochem. 24, 206.

LUNDEGÅRDH, H. (1945). Absorption, transport and exudation of inorganic ions by the roots. Ark. Bot. 32 A, $12,1$.

Mrtchell, P. (1949). A new technique for stirred aerated culture. Nature, Lond. 164, 846.

Mitchend, P. (1953). Transport of phosphate across the surface of Micrococcus pyogenes: nature of the cell 'inorganic phosphate'. J. gen. Microbiol. 9, 273.

Mrtchell, P. \& Moyle, J. (1951 a). Relationships between cell growth, surface properties and nucleic acid production in normal and penicillin-treated Micrococcus pyogenes. J. gen. Microbiol. 5, 421.

Mitchell, P. \& Moyle, J. (1951 b). The glycerophospho-protein complex envelope of Micrococcus pyogenes. J. gen. Microbiol. 5, 981.

Nelson, V. (1944). A photometric adaptation of the somogyi method for the determination of glucose. J. biol. Chem. 153, 375 .

Roberts, R. B. \& Roberts, I. Z. (1950). Potassium metabolism in Escherichia coli. III. Interrelationship of potassium and phosphorus metabolism. J. cell. comp. Physiol. 36, 15. 
Schmidt, G., Hecht, L. \& Thannhauser, S. J. (1948). The behaviour of the nucleic acids during the early development of the sea urchin egg. J. gen. Physiol. 31, 203.

Schmidt, G. \& Thannhauser, S. J. (1945). A method for the determination of desoxyribonucleic acid, ribonucleic acid and phosphoproteins in animal tissues. J. biol. Chem. $161,83$.

SchoENHEIMER, R. (1942). The dynamic state of the body constituents. Harvard Univ. Press, Cambridge, Mass.

Ussing, H. H. (1947). Interpretation of the exchange of radio-sodium in isolated muscle. Nature, Lond. 160, 262.

Villee, C. A., Lowens, M., Gordon, M., Leonard, E. \& Rich, A. (1949). The incorporation of ${ }^{82} \mathrm{P}$ into the nucleoproteins and phosphoproteins of the developing sea urchin embryo. J. cell. comp. Physiol. 33, 93.

(Received 28 March 1953) 